\title{
POTENSI PERMUKIMAN PERAJIN PERAK TRADISIONAL BERBASIS ARSITEKTUR DAN EKONOMI KREATIF DI DESA CELUK, GIANYAR
}

\author{
Ni Putu Ratih Pradnyaswari Anasta Putri ${ }^{1}$, Anak Agung Gede Raka Gunawarman², \\ Ni Luh Anik Puspa Ningsih ${ }^{3}$ \\ ${ }^{1,2}$ Program Studi Arsitektur, Fakultas Teknik dan Perencanaan, Universitas Warmadewa, Indonesia \\ ${ }^{3}$ Program Studi Manajemen, Fakultas Teknik dan Perencanaan, Universitas Warmadewa, Indonesia \\ e-mail: pradnyaswari.anasta@gmail.com ${ }^{1}$
}

How to cite (in APA style):

Putri, N. P. R. P. A., Gunawarman, A. A. G. R. \& Ningsih, N. L. A. P. (2020). Potensi Permukiman Perajin Perak Tradisional Berbasis Arsitektur Dan Ekonomi Kreatif Di Desa Celuk, Gianyar. Undagi : Jurnal Ilmiah Jurusan Arsitektur Universitas Warmadewa. 8(1), pp.37-44.

\begin{abstract}
The silver handicraft industry in Celuk Village, Gianyar is the second largest silver craft center in Indonesia after the Gede city of Yogyakarta. The superiority of silver handicrafts in Celuk village is the unique jewelery design and still going through the traditional craftsmanship process as well as being a tourist destination. In addition, the situation around Celuk Village is seen experiencing rapid development in terms of tourist destinations. The existence of these destinations has the opportunity to optimize the traditional silver crafters' settlements as tourist accommodation. There is a need for research on criteria for tourism accommodation standards, policies, and future governance to be the outcome of this research. The draft academic manuscript which can be a reference for issuing standardization and rules of custom or service is expected to encourage Celuk Village to be the best tourist destination in Gianyar Regency that is independently and able to meet the welfare of its village residents through the existing tourism potential. By using explorative qualitative research methods, found the potential of silver crafters settlements in the village of Celuk where in addition to the space to live and work, there are areas that can be used as guest houses or homestays.
\end{abstract}

Keywords: settlement; tourism; potential

\begin{abstract}
ABSTRAK
Industri kerajinan perak di Desa Celuk, Gianyar merupakan sentra kerajinan perak terbesar kedua di Indonesia setelah kota Gede Yogyakarta. Keunggulan kerajinan perak di desa Celuk adalah pada desain perhiasan yang unik dan masih melalui proses pengerjaan secara tradisional (handmade) sekaligus menjadi destinasi wisata. Selain itu, keadaan sekitar Desa Celuk terlihat mengalami perkembangan pesat dalam hal daerah tujuan wisata (DTW). Keberadaan destinasi tersebut berpeluang untuk mengoptimalkan permukiman perajin perak tradisional sebagai akomodasi wisata. Perlu adanya penelitian tentang kriteria standar akomodasi wisata, kebijakan, serta tata kelola kedepan menjadi luaran hasil dari penelitian ini. Draft naskah akademik yang dapat menjadi acuan untuk mengeluarkan standarisasi dan aturan-aturan adat atau dinas diharapkan dapat mendorong Desa Celuk menjadi destinasi wisata yang terbaik di Kabupaten Gianyar yang secara mandiri dan mampu memenuhi kesejahteraan warga desanya melalui potensi wisata yang ada. Dengan menggunakan metode penelitian kualitatif eksploratif, ditemukan potensi permukiman perajin perak di Desa Celuk dimana selain terdapat ruangan untuk tinggal dan bekerja, terdapat area yang bisa difungsikan sebagai guest house atau homestay.
\end{abstract}

Kata kunci: permukiman; pariwisata; potensi

PENDAHULUAN
Bali merupakan salah satu daerah destinasi wisata di Indonesia bahkan menjadi daerah 
wisata terbaik dunia versi Trip Advisor 2018. Bali memiliki karakteristik perekonomian yang sangat unik yang disokong oleh sektor pariwisata. Pariwisata di Bali berkembang dengan dukungan sektor pertanian, landscape yang asri, bangunan-bangunan tradisional yang masih lestari, sektor jasa-jasa pendukung pariwisata, serta ekonomi kreatif.

Ekonomi Bali yang dominan dipengaruhi oleh kinerja pariwisata, tentu tidak terlepas dari peranan sektor industri pengolahan, terutama industri kerajinan sebagai pendukung kemajuan kepariwisataan di Bali. Potensi industri kerajinan di Bali terbukti melalui kontribusi industri kerajinan terhadap ekspor provinsi Bali. Melalui tujuan eskpor diantaranya Amerika Serikat, Singapura, Jepang, Australia dan Thailand, industri kerajinan mampu menghasilkan devisa sebesar 93,26 juta dolar atau 41,90\% (Disperindag Provinsi Bali, 2013).

Berkembangnya industri kerajinan di Bali, selain karena dampak multiplier effect dari pariwisata Bali, tetapi juga disebabkan karena produknya merupakan produk inovatif dan kreatif yang digali dari kearifan lokal, yang membedakan produk ini dengan produk negara lain. Industri kerajinan perak merupakan salah satu potensi yang dimiliki Provinsi Bali dengan produk yang unik.

Salah satu destinasi wisata Bali yang memiliki produk unik tersebut adalah Desa Celuk dengan produk kerajinan peraknya. Kerajinan perak Desa Celuk, Sukawati, Kabupaten Gianyar, sudah mulai dikenal tepatnya pada tahun 1915 yang dipelopori oleh seorang pande bernama I Nyoman Gati.

Industri kerajinan perak di desa Celuk, Gianyar merupakan sentra kerajinan perak terbesar kedua di Indonesia setelah kota Gede Yogyakarta. Keunggulan kerajinan perak di desa Celuk adalah pada desain perhiasan yang unik dan masih melalui proses pengerjaan secara tradisional (handmade). Jumlah perajin perak di desa celuk tercatat 300 perajin pada Maret 2011 (Celuk Design Centre, 2011). Tidak semua perajin mampu berkembang. Berbagai hasil riset menunjukkan bahwa permasalahan yang dihadapi dalam perkembangan industri kecil menengah termasuk industri kecil kerajinan perak menghadapi berbagai permasalahan yang diklasifikasikan menjadi tiga yaitu basic problem (akses modal, legalitas usaha, SDM, pengembangan produk dan akses pemasaran), advance problem (pemahaman secara teoritis pengembangan usaha, permasalahan hukum menyangkut legalitas usaha) serta intermediate problem yaitu kemampuan internal unit usaha dalam memecahkan permasalahan yang dihdapi (Hadiwidjaja dan Hartati, 2017).

Melihat bagaimana mendunianya Desa Celuk sebagai Desa perajin perak di kancah internasional, nasional, maupun lokal, aspek permukimannya juga dapat diangkat sebagai suatu objek daya tarik wisata. Permukiman dari perajin perak yang ada di Desa Celuk tentunya terdiri atas rumah-rumah berunsur tradisional Bali yang ruang-ruang didalamnya terpengaruh oleh aktivitas perajin perak. Aktivitas tersebut menghasilkan tata ruang yang unik dan mencerminkan budaya lokal. Daya tarik wisata dari permukimannya adalah melihat langsung keseharian warga mulai dari pagi hingga malam hari, dengan demikian secara tak langsung wisatawan akan dapat menikmati budaya Celuk melalui mengamati keseharian warga Desa Celuk yang berprofesi sebagai perajin perak, sekaligus menikmati suasana tata ruang rumah tradisional Bali.

\section{METODE PENELITIAN}

Metode penelitian yang digunakan adalah metode penelitian kualitatif. Penelitian kualitatif digunakan untuk meneliti objek yang alamiah, tidak dimanipulasi oleh peneliti,baik saat peneliti memasuki objek penelitian maupun setelah usai penelitian. Penelitian kualitatif digunakan untuk mendapatkan data yang mendalam, suatu data yang mengandung makna (Sugiyono, 2008 dalam Putri, 2016:83).

Fokus penelitian ini adalah memperoleh informasi mengenai ruang-ruang yang ada di dalam rumah mereka, potensi permukiman yang mampu menunjang kegiatan pariwisata, dan kesesuaian ruang-ruang guna menunjang pariwisata. Lokus penelitian ini lebih mengarah pada permukiman perajin perak yang masih bersifat tradisional di Desa Celuk, Sukawati Gianyar. Langkah awal metode ini adalah dengan observasi mengenai permukiman perajin tradisional yang ada, melakukan pemetaan sederhana, dan 
memberikan gambaran mengenai potensi permukiman yang ada.

\section{HASIL DAN PEMBAHASAN}

Keunikan dari kerajinan perak di Desa Celuk memberikan nilai keindahan tersendiri sehingga Desa Celuk dijadikan objek wisata kerajinan perak pada tahun 1976. Tahun 1976 merupakan tahun dimulainya perkembangan pariwisata Bali. Pada tahun tersebut selain Pantai Kuta dan Kintamani, Desa Celuk juga sudah mulai ramai dikunjungi dan sudah mendunia hingga saat ini. Meskipun telah mendunia, namun nyatanya kini Desa Celuk mulai ditinggalkan. Hal ini disebabkan oleh beberapa faktor, antara lain : (1) menjamurnya pusat oleh-oleh yang ada di Bali; (2) terdapat factory khusus perak yang ada di perbatasan Gianyar dan Denpasar yang menampilkan teknologi yang lebih canggih dan produksi skala besar sehingga perajin perak tradisional Celuk mulai ditinggalkan; (3) susahnya mencari generasi penerus yang mau dan mampu mengembangkan kerajinan perak Celuk; dan (4) kurangnya tujuan wisata yang ditawarkan di Desa Celuk.

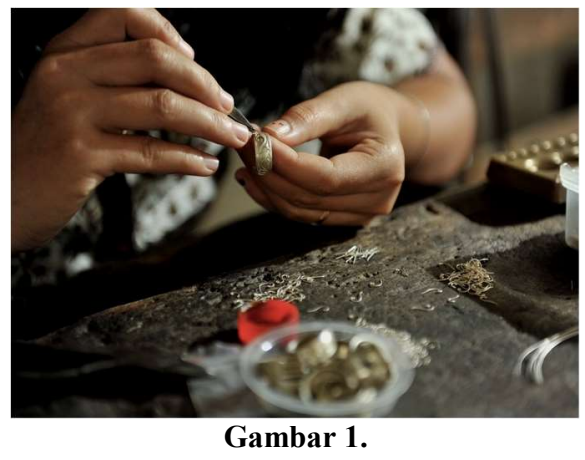

Kerajinan Perak Desa Celuk

(Sumber: Dokumentasi Peneliti, 2020)

Permukiman dari perajin perak yang ada di Desa Celuk tentunya terdiri atas rumah-rumah berunsur tradisional Bali yang ruang-ruang didalamnya terpengaruh oleh aktivitas perajin perak. Aktivitas tersebut menghasilkan tata ruang yang unik dan mencerminkan budaya lokal. Daya tarik wisata dari permukimannya adalah melihat langsung keseharian warga mulai dari pagi hingga malam hari, dengan demikian secara tak langsung wisatawan akan dapat menikmati budaya Celuk melalui mengamati keseharian warga Desa Celuk yang berprofesi sebagai perajin perak, sekaligus menikmati suasana tata ruang rumah tradisional Bali.

Keadaan sekitar Desa Celuk terlihat mengalami perkembangan pesat dalam hal destinasi wisata (DTW). Perkembangan tersebut ditandai dengan munculnya objek wisata DAS Tukad Oos, Pura Dalem Celuk, Bali Swing. Untuk wisata kuliner terdapat lawar Pak Gading, Sentra Kuliner Sinoman Galuh Mantri. Wisata Seni dan Budaya terdapat Sanggar Tari Celuk Kita Art Community, silver class dari Celuk Design Centre. Setiap tahunnya Desa Celuk juga mengadakan event seperti Celuk Jewelry Festival.

Melihat sudah cukup banyaknya terdapat DTW atau daya tarik wisata, namun diseputaran Desa Celuk belum terdapat akomodasi pariwisata yang memadai. Mayoritas wisatawan yang berkunjung ke Desa Celuk, menginap di Ubud atau Sanur, hal ini membuat Desa Celuk hanya sebatas sebagai tempat berkunjung wisata, bukan sebagai tempat dimana para wisatawan dapat menghabiskan waktu penuhnya untuk mengenal lebih dekat keunikan Desa Celuk.

Melihat banyaknya kunjungan wisatawan menyebabkan Desa Celuk harus mampu menyiapkan fasilitas-fasilitas pendukung pariwisata untuk dapat meningkatkan daya saing dan pendapatan desanya. Permasalahan yang timbul di lapangan adalah banyaknya lahan yang tidak difungsikan secara maksimal di Desa Celuk sehingga banyak sekali lahanlahan yang sedikit kurang terurus dan kumuh.

\section{Pola Ruang Permukiman Perajin Perak di Desa Celuk}

Menurut para perajin perak di Desa Celuk, rumah-rumah yang ada di Desa Celuk dahulunya memiliki pola permukiman tradisional yang terdiri atas Merajan, Bale Daja, Bale Dauh, Bale Dangin, Paon, Jineng. Dimana pola perumahan tradisional tersebut hanya memenuhi kebutuhan utamanya saja. Namun, seiring dengan perkembangan zaman dimana masyarakat Celuk yang dahulunya masyarakat agraria ke industri kerajinan dan industri pariwisata. Pola permukiman tersebut berubah dengan tambahan beberapa ruang 
khusus seperti toko (artshop) ataupun workshop perajin perak sebagai ruang kerjanya. Perubahan yang terjadi pada permukiman di Desa Celuk akibat perubahan mata pencaharian penduduknya yang dahulu bertani menjadi pengrajin perak tradisional dengan kualitas ekspor.

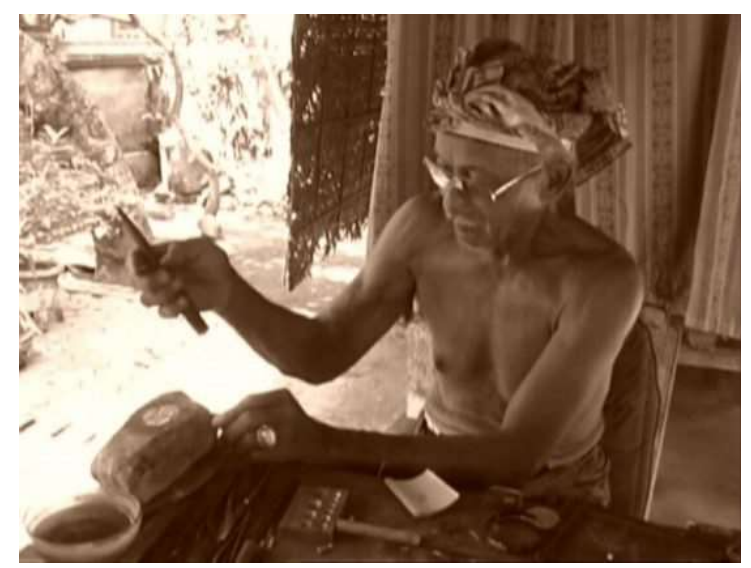

Gambar 1.

Ruang Pandai Perak Celuk tahun 1960-an (Sumber : Celuk Design Centre, 2011)

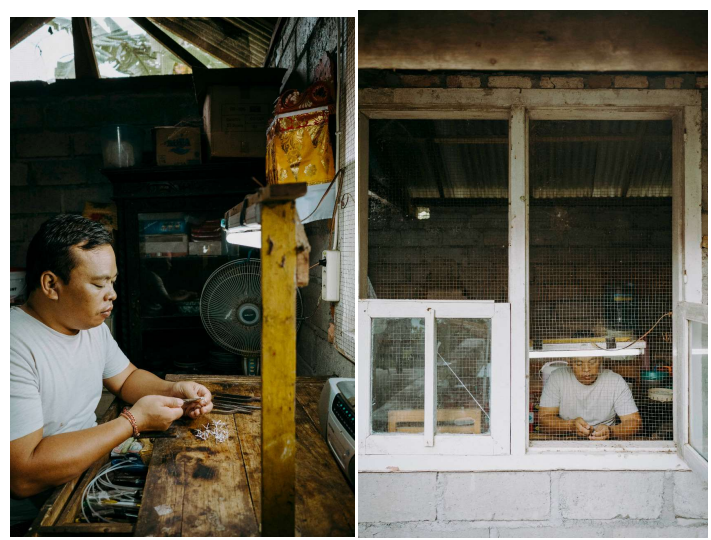

Gambar 2.

Ruang Tambahan Sebagai Area Kerja yang Diletakkan Bersebelahan dengan Dapur

(Sumber : Observasi, 2020)

Sehingga dalam pola ruang aktivitas secara mikro terdapat pola ruang aktivitas hunian dan aktivitas kerja. Beradasarkan data perajin perak yang telah dianalisis memiliki persamaan dimana pola ruang tambahan sebagai ruang kerja dan toko umumnya berada di areal depan rumah (toko) dan dekat areal dapur (untuk aktvitas perajin perak). Peletakkan area kerja dekat area dapur disebabkan oleh kepercayaan umat Hindu bahwa api (untuk menempa perak) sebagai simbol perwujudan Dewa Brahma (selatan bagian dapur).

Selain penambahan aktivitas kerja, para perajin perak di Desa Celuk juga memiliki potensi berupa ruang / bale yang tidak digunakan sebagai hunian. Umumnya balebale ini berdiri sebagai kebutuhan hunian sementara bagi kerabat/anak/saudara yang sudah menikah keluar dan sewaktu-waktu kembali ke kampung halaman. Keberadaan bale yang tidak ditempati tersebut juga akibat dari proses perkembangan keluarga perajin perak yang lebih memilih untuk tinggal terpisah dari keluarganya meskipun masih dalam satu desa (ngarangin). Akibatnya, banyak bale yang tidak dihuni/ dihuni sewaktu-waktu yang justru menjadi potensi tersendiri bagi Desa Wisata Celuk untuk dimanfaatkan sebagai bagian dari akomodasi pariwisata desa.

\section{Potensi Permukiman Tradisional Perajin Perak Desa Celuk, Sukawati, Gianyar}

Pariwisata dan tingkat ekonomi masyarakat dengan sendirinya akan meningkat seiring dengan keberadaan fasilitas yang tersedia di kawasan wisata. Meskipun Desa Celuk kini memiliki potensi wisata alam, aksesbilitas yang baik, wisata budaya dan kesenian, serta wisata kuliner. Namun hal tersebut kurang lengkap tanpa adanya akomodasi pariwisata.

Melalui penelitian dan observasi yang telah dilakukan, terdapat beberapa potensi hunian perajin perak yang sudah dapat difungsikan sebagai akomodasi pariwisata. Potensi permukiman perajin perak tradisional di Desa Celuk memiliki beberapa kekuatan sehingga mampu dikembangkan nantinya menjadi akomoadi pariwisata.

a. Potensi Bangunan Permukiman

Bangunan-bangunan permukiman perajin perak tradisional di Desa Celuk lebih banyak menggunakan pola natah dengan rumah-rumah dengan masa majemuk. Selain pola permukimannya, pada permukiman rumah perajin perak tradisional Celuk juga memiliki arsitektur yang beragam mulai dari tradisional hingga vernacular.

Selain bangunannya, potensi yang dimiliki adalah dari suasana sekitar bangunan permukiman, dimana Desa Celuk sendiri 
masih merupakan desa asli yang mayoritas penduduknya berasal dari Celuk. Hal ini menjadi salah satu kekuatan dan daya tarik bagi wisatawan yang akan tinggal menginap. Karena akan merasakan sendiri suasana pedesaan yang cukup kental di Desa Celuk.

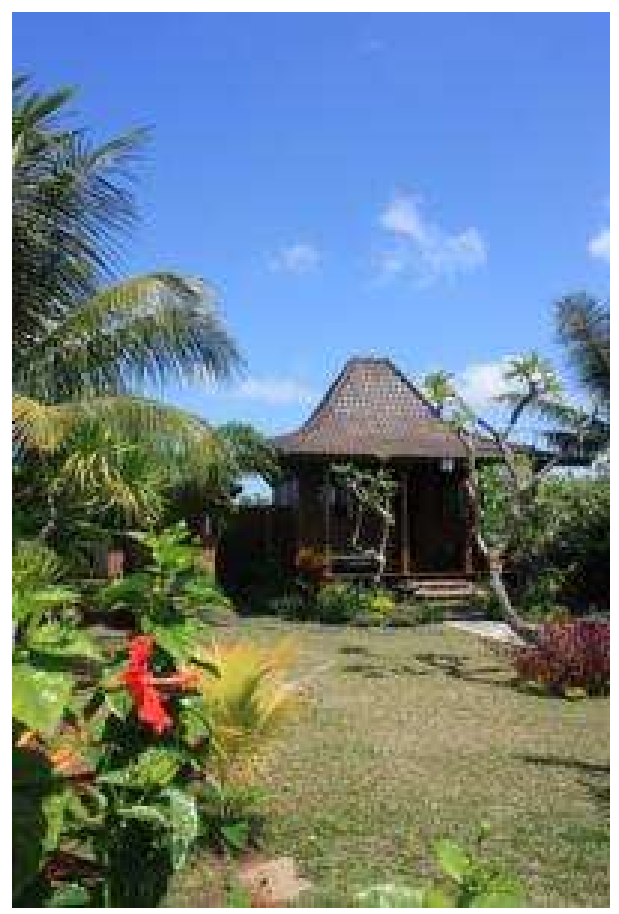

Gambar 3.

Permukiman Bapak Wayan Adiguna yang bergaya vernacular, sudah difungsikan sebagai akomodasi pariwisata sejak 2018

(Sumber : Observasi, 2020)

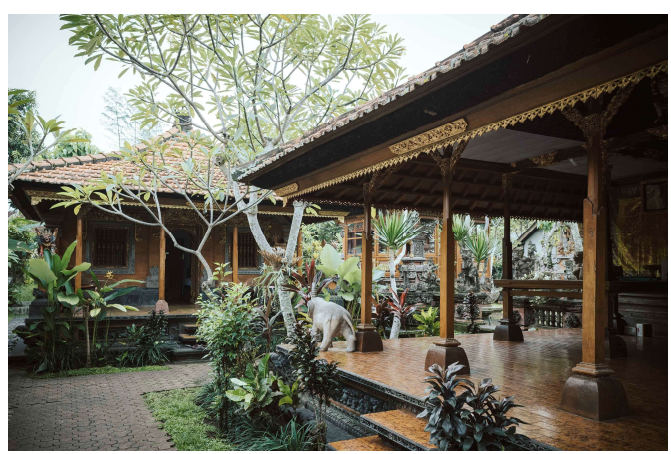

Gambar 4.

Permukiman Bapak Made Rawa yang bergaya tradisional dengan konsep natah, saat ini masih kosong dan dapat difungsikan sebagai akomodasi pariwisata.

(Sumber : Observasi, 2020)

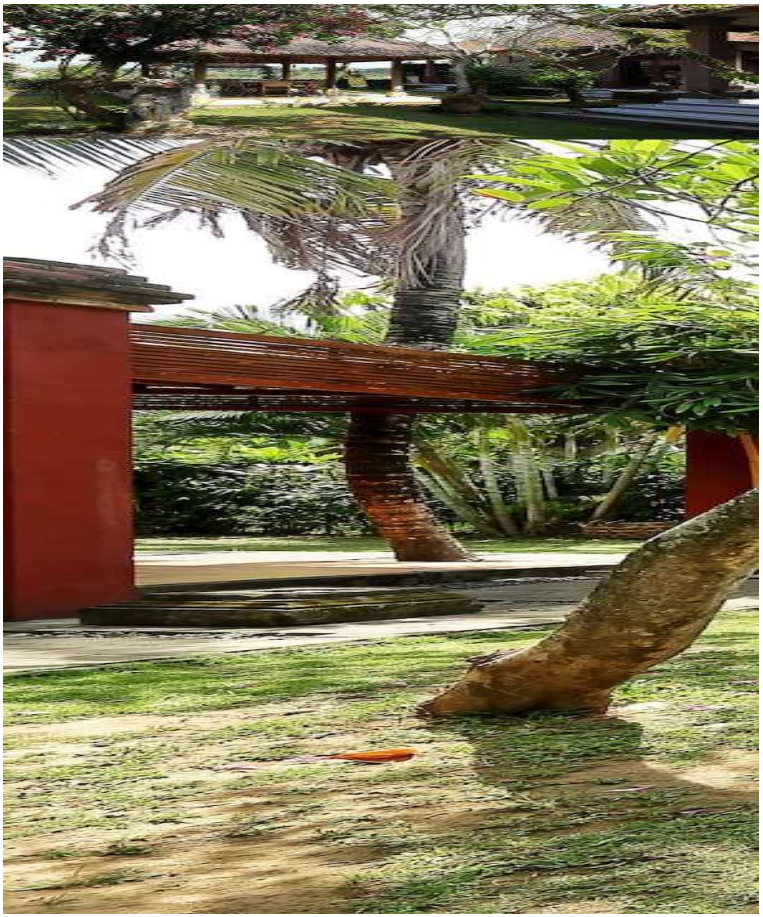

Gambar 5.

Permukiman Bapak Ketut Widi yang bergaya tropis dengan konsep natah, saat ini masih kosong dan dapat difungsikan sebagai akomodasi pariwisata.

(Sumber : Observasi, 2020)

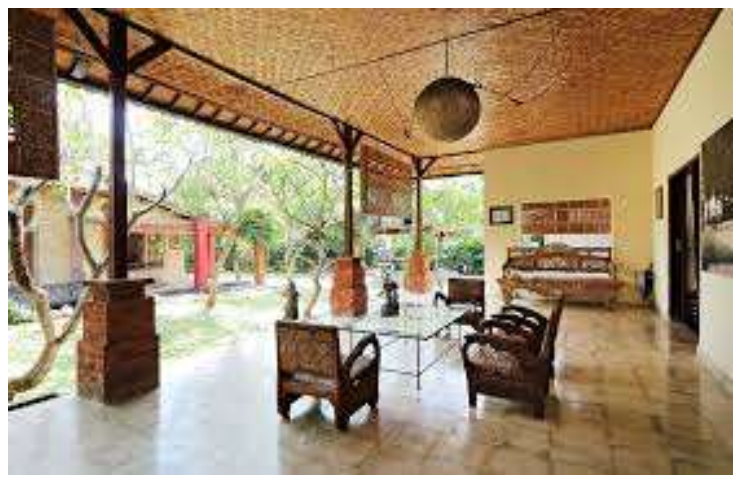

Gambar 6.

Permukiman Bapak Ketut Widi yang bergaya kolonial-art deco saat ini telah difungsikan sebagai akomodasi pariwisata.

(Sumber : Observasi, 2020)

Satu dari keempat permukiman di Desa Celuk yang dijadikan studi kasus, sejak tahun 2018 telah diubah fungsinya menjadi akomodasi pariwisata. Bangunan-bangunan ini umumnya berdiri diluar sikut satak pekarangan rumah dan memang difungsikan sebagai area untuk tamu. Hanya saja sampai saat ini ketiga permukiman lainnya hanya diperuntukkan untuk keluarga atau kerabat dekat saja, sehingga seringkali tidak digunakan. 
Berdasarkan wawancara dengan pemilik Bapak Wayan Adiguna, bangunan permukiman yang dijadikan akomodasi pariwisata lebih sering dihuni oleh wisatawan mancanegara yang tinggal dan menetap di Bali selama periode waktu yang cukup lama (3-12 bulan). Wisatawan yang tinggal umumnya memilki tujuan bisnis dengan masyarakat Celuk ataupun ingin belajar lebih dalam mengenai kerajinan perak Celuk. Bangunan permukiman ini berubah menjadi akomodasi wisata dikarenakan perkembangan akan kebutuhan hidup dan pemeliharaan bangunan, sehingga tercetus ide untuk menyewakan sebagai akomodasi pariwisata.

Pada kasus lain, bangunan permukiman belum pernah disewakan sebagai akomodasi pariwisata akibat beberapa faktor, antara lain : (1) faktor kebiasaan, dimana masyarakat Celuk sejak dahulu jarang membuka "rumah" mereka untuk orang asing; (2) Desa Celuk didominasi oleh perajin perak tradisional, yang dimana ketika wisatawan datang ke Celuk untuk belajar membuat perak umumnya durasinya sangat cepat sehingga tidak membutuhkan akomodasi untuk tinggal dan menetap dalam waktu lama; (3) tidak menahunya masyarakat perajin perak dalam memasarkan "rumah" mereka; dan (4) belum adanya tata kelola dan strategi pengembangan yang dimiliki oleh Desa Adat Celuk.

Berdasarkan penelitian yang telah dilakukan, sesungguhnya cukup banyak permukiman yang dapat dijadikan akomodasi pariwisata. Permukiman perajin perak tradisional di Desa Celuk memiliki potensi sebagai wisata berbasis budaya, hanya saja perlu pemeliharaan bangunan serta meningkatkan kemampuan masyarakatnya untuk meningkatkan nilai ekonomi yang dimiliki agar siap menampung wisatawan yang datang. Selain itu manajemen tata kelola desa mengenai akomodasi pariwisata juga harus ditingkatkan.

\section{b. Pola Kebiasaan Masyarakat}

Pola kebiasaan masyarakat Desa Celuk sejak zaman dahulu hingga sekarang tidak terlalu banyak berubah meskipun masyarakatnya banyak bersinggungan dengan orang luar dan wisatawan mancanegara. Masyarakat Celuk tetap memegang teguh tradisi yang ditinggalkan nenek moyang turun temurun, hal ini juga terlihat dari motif-motif desain perhiasan yang diciptakan masih memegang teguh beberapa motif lama seperti liman paya, bungan gonda, kembang genjer, jawan, dan bun.

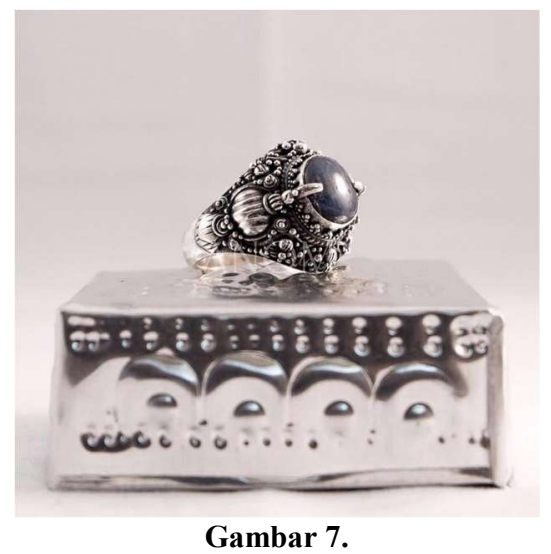

Motif Bun Desain Perhiasan Desa Celuk (Sumber : Dokumen Peneliti, 2020)

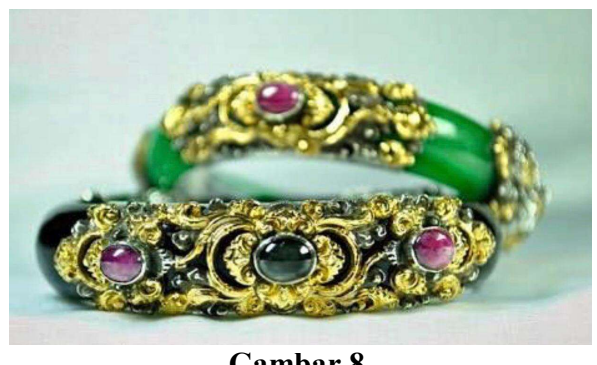

Motif Tatah Desain Perhiasan Desa Celuk (Sumber : Dokumen Peneliti, 2020)

Pola kebiasaan masyarakat ini juga berpengaruh pada pola hunian, dimana masyarakat Celuk sangat jarang merubah pola hunian yang berada di natah atau wilayah permukiman aslinya. Umumnya perubahan hanya dilakukan dengan penambahan ruang tanpa merusak sikut satak (pedoman dasar ukuran rumah berdasarkan ukuran tubuh pemiliknya).

Masyarakat Celuk layaknya masyarakat pedesaan lain juga lebih memilih berkumpul dengan keluarga ataupun tetangga dalam ruang-ruang komunal yang diciptakan secara berkelompok (misal: pada area dekat permandian umum, balai tempekkan, arena olahraga, dan warung-warung kopi sederhana dekat rumah). 
c. Aksesbilitas

Aksesbilitas menjadi salah satu daya tarik lainnya yang nantinya dapat dikembangkan. Hal ini diakibatkan oleh posisi Desa Celuk yang sangat dekat menuju Sukawati, Ubud, maupun pusat kota Denpasar. Sehingga diharapkan, wisatawan yang akan berkunjung ke Sukawati, Ubud, maupun Denpasar dapat memiliki pilihan untuk menginap dan tinggal sementara waktu di Desa Celuk.

Melalui tata kelola yang baik, saranaprasarana, dan didukung oleh aksesbilitas yang mudah dijangkau sangat diyakini bahwa permukiman perajin perak tradisional Desa Celuk akan menjadi sebuah potensi baru.

d. Kelengkapan Produk Wisata sebagai Penunjang Ekonomi Kreatif

Sesungguhnya produk wisata di Desa Celuk dapat dikatakan lengkap mulai dari wisata alam, budaya, kesenian, produk kerajinan, dan akomodasi. Melalui potensi tersebut sesungguhnya Desa Celuk mampu berkembang menjadi desa wisata berbasis ekonomi kreatif. Hanya saja dibutuhkan peningkatan kualitas penduduknya sehingga mampu mensinergikan potensi tersebut dengan baik. Perlunya dukungan perangkat desa juga menjadi salah satu aspek dalam mendukung kualitas wisata di Desa Celuk. Apabila hal tersebut telah bersinergi dengan baik, diharapkan Desa Celuk dapat menjadi salah satu desa wisata.

\section{SIMPULAN}

Desa Celuk sendiri memiliki potensi wisata yang cukup lengkap. Selain potensi wisaya alam, budaya, produk kesenian, Desa Celuk juga memiliki potensi wisata permukiman tradisional. Namun potensi wisata akomodasi ini tidak terwadahi dengan baik diakibatkan oleh beberapa faktor, antara lain : (1) faktor kebiasaan, dimana masyarakat Celuk sejak dahulu jarang membuka "rumah" mereka untuk orang asing; (2) Desa Celuk didominasi oleh perajin perak tradisional, yang dimana ketika wisatawan datang ke Celuk untuk belajar membuat perak umumnya durasinya sangat cepat sehingga tidak membutuhkan akomodasi untuk tinggal dan menetap dalam waktu lama; (3) tidak menahunya masyarakat perajin perak dalam memasarkan "rumah" mereka; dan (4) belum adanya tata kelola dan strategi pengembangan yang dimiliki oleh Desa Adat Celuk.

Dalam kaitannya dengan potensi permukiman perajin perak tradisional berdasarkan potensi arsitekturnya dapat dilihat, antara lain: (1) Desa Celuk memiliki gaya arsitektur yang beragam mulai tradisional hingga neo vernacular; (2) pola permukimannya masih menggunakan pola natah dengan bangunan majemuk (terdiri dari beberapa bale); (3) banyak terdapat bangunanbangunan religius yang relatif tua terdapat di beberapa permukiman sehingga menarik untuk dijadikan daya tarik; (4) terdapat ruang tambahan untuk pandai perak berupa prapen (tempat pandai perak) yang masih tradisional.

Jika ditinjau dari potensi ekonomi kreatif, permukiman perajin perak tradisional Desa Celuk memiliki beberapa potensi antara lain : (1) banyaknya permukiman perajin perak di Desa Celuk sehingga cenderung menjadi sentra industri/produksi kerajinan perak dari skala kecil hingga besar dari tradisional hingga kontemporer; (2) banyaknya toko-toko yang berdiri dalam satu tempat meningkatkan efektifitas dalam mobilitas bekerja sehingga secara ekonomi mampu meningkatkan nilai ekonomi.

Berdasarkan potensi yang dimiliki, diharapkan Desa Celuk mampu menjadi desa wisata yang berwawasan budaya, alam, dan kesenian.

\section{DAFTAR PUSTAKA}

Attar, M., Hakim, L., \& Yanuwiadi, B. (2013). Analisis Potensi Dan Arahan Strategi Kebijakan Pengembangan Desa Ekowisata Di Kecamatan Bumiaji - Kota Batu. Journal of Indonesian Tourism and Development Studies Vol.1, No.2, April, 68-78.

Celuk Design Centre. (2011). Jewelry of Bali : History of Jeweler and Celuk Design Centre : Celuk, Bali

Disperindag Propinsi Bali. (2013, 07 04). Disperindag Propinsi Bali. Retrieved 04 01, 2019, from Disperindag Propinsi Bali: http://www.disperindag.baliprov.go.id

Ernadia, L., Murtini, T. W., \& Rukayah, R. (2017). Perubahan Lingkungan dan Tata Ruang Rumah Tinggal di Desa Wisata Kandri. 
Tesa Arsitektur Volume 15 | Nomor 1, 4153.

Hadiwidjaja, Rini Dwiyani dan Hartati, Noorina. 2017. Tinjauan Umum Usaha Mikro Kecil dan Menengah di Indonesia : Persamalahan dan Strategi. Prosiding Seminar Nasional Fakultas Ekonomi Universitas Terbuka

Ernadia, L., Murtini, T. W., \& Rukayah, R. (2017). Perubahan Lingkungan dan Tata Ruang Rumah Tinggal di Desa Wisata Kandri. Tesa Arsitektur Volume 15 | Nomor 1, 4153.1

Putri, Ni Putu Ratih Pradnyaswari Anasta. (2016). Perkembangan Arsitektur pada Palebahan di Puri Agung Peliatan, Ubud : Yogyakarta

Sumar'in, Andiono, \& Yuliansyah. (2017). Pengembangan Ekonomi Kreatif Berbasis Wisata Budaya: Studi Kasus pada Pengrajin Tenun di Kabupaten Sambas. Jurnal Ekonomi Bisnis dan Kewirausahaan 2017, Vol. 6, No. 1, 1-17. 